\title{
Psychosomatic aspects of healthcare facility design solutions
}

\author{
Ewa Pruszewicz-Sipińska \\ ewa.pruszewicz-sipinska@put.poznan.pl
}

\author{
Agata Anna Gawlak \\ agata.gawlak@put.poznan.pl

\section{Magda Matuszewska \\ magda.matuszewska@put.poznan.pl}

Faculty of Architecture, Institute of Architecture, Urbanism and Heritage, Poznan University of Technology

\begin{abstract}
The purpose of this paper is to present the social and psychological aspects of the impact of architecture of a hospital on all its users.

The authors analyse the impact of factors shaping the architectural space of a hospital on the behaviour of patients and on the mutual relations between all the participants of the hospitalisation process.

The hospital space has been presented from the point of view of the psychophysical needs of a patient, from the point of view of the medical staff and the visitors. The analysis includes the assessment of the quality of architectural space of a hospital as a place intended for the medical treatment, which is to facilitate the recovery of the patient and fast response of the staff in emergency situations.
\end{abstract}

\section{Key words:}

\section{Architectural design as a determinant of the patients' recovery}

"Architecture is a form of cultural adaptation of man to the natural and social environment. It is a culture of shaping spatial barriers and distances that protect man against adverse effects of the surroundings, that compensate for his biological limitations, regulate the nature and intensity of his contacts with other space co-users (..) Formal and spatial defects of the interior design (...) often pose certain excessive adaptation requirements and result in the feeling of stress, discomfort and threat" (Czyński, 2006).

The data of the Central Statistical Office clearly shows that, on the one hand, the society is ageing (number of people over 60 is increasing) and, on the other hand, the birth rate is going down. It is estimated that in the next 10 years the percentage of the elderly will reach about $28 \%$ (10 million). Whereas in further decades, if this trends continues, in 2050 the percentage of the elderly will be around $40 \%$. Such forecasts indicate that the senior health care services will be in higher and higher demand. The presently operating health care centres will require extension or new facilities will have to be built. This may pose quite a challenge bearing in mind higher and higher expectations regarding the quality of health care centres.

Architecture intentionally predetermines certain types of human behaviour. By appropriately shaped building space, it underlies the mutual relations between the users. (Bańka, 1985). A hospital, being a building of a complex program of functions and of a diversified form, is a specific place of compulsory stay of persons in uncomfortable conditions. This obviously refers to their poor health condition but not only that. Hospital interior can contribute to the well-being of the admitted patients. Illegible functional layout or complicated circulation that hinders orientation may make the patients feel lost, uncertain or insecure. 
The ability to master the barriers of the man-made environment is much reduced in case of the sick, the elderly or the disabled. This adversely affects their adaptability skills and the feeling of safety in contact with direct environment (Czyński, 2006). Architecture of health care facilities poses certain "adaptation requirements" for the users.

As M. Czyński observes, human health is a one, indivisible whole. Disorders in somatic, psychological, social or spiritual zones mutually influence one another.

Architecture of health care facilities is more anthropocentric than architecture of any other types of buildings because it has to account for the biological limitations of human nature.

Internal rules and regulations applicable in hospitals significantly reduce the patients' options of having the space they use under their own control (Bell, Greene, Fisher, Baum, 2004).

It may, however, be assumed that the relations between the patients and the hospital environment can be respectively moderated to facilitate well-being and recovery process of the patients. Proper design of space shall assure the patients with optimum comfort during their hospitalization, i.e. at the moment of hospital admission, diagnostic tests and the overall treatment process.

Evidence-based Design analyses unambiguously co-relate the quality of the building environment with the recovery rate in patients.

Building space, wrongly designed by an architect, may translate into the patient's feeling of alienation, fear or stress, whereas we would expect from the architecture of health care facilities to exert quite the opposite effect (the feeling of relax, safety and harmony). It's a natural human need to feel safe at the psychophysical and emotional level. That is why application of relevant design solutions, which positively affect the mutual relations between the patients by providing them, on the one hand, with private space and, on the other hand, with space facilitating social interaction in the hospital environment, is so important.

\section{Architecture of a hospital and public space}

"Architecture has its own realm. It has a special physical relationship with life. I do not think of it primarily as either a message or a symbol but as an envelope and background for life which goes in and around it, a sensitive container of the rhythm of footsteps on the floor, for concentration of work and for silence of sleep" (Zumthor, 2010).

As early as in the middle of the previous century, paediatric hospitals were recommended to be designed to create optimum conditions for the patients, thus allowing for optimum daylight, accounting for green areas and suitable colours to create positive and stimulating environment for the hospitalised children separated from their families, not to scare them with white and unfamiliar interiors. [Fig.1]

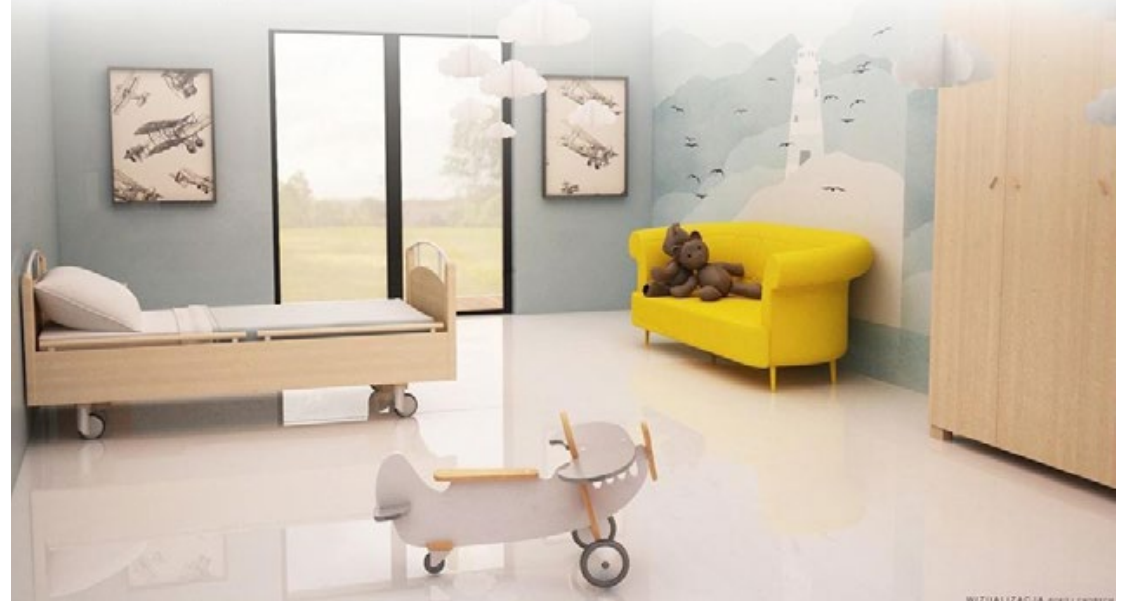

Fig. 1. Interior design of the hospital room in a paediatric hospital.

Author: MSc, architect engineer Magdalena Jakubowicz; Thesis supervisor: PhD, architect engineer A. Gawlak 
This new approach to space of health care facilities is further discussed by Szafranowicz, in his publication of 2005, where he defined healing environment as a set of spatial and functional solutions in health care facilities combined with the know-how and medical technologies, that have a nurturing and therapeutic effect on the patient. Due to complex functional programs and circulation paths, architecture of health care facilities is a very complex structure, which can be divided into three zones (A,B,C). [Fig.2]

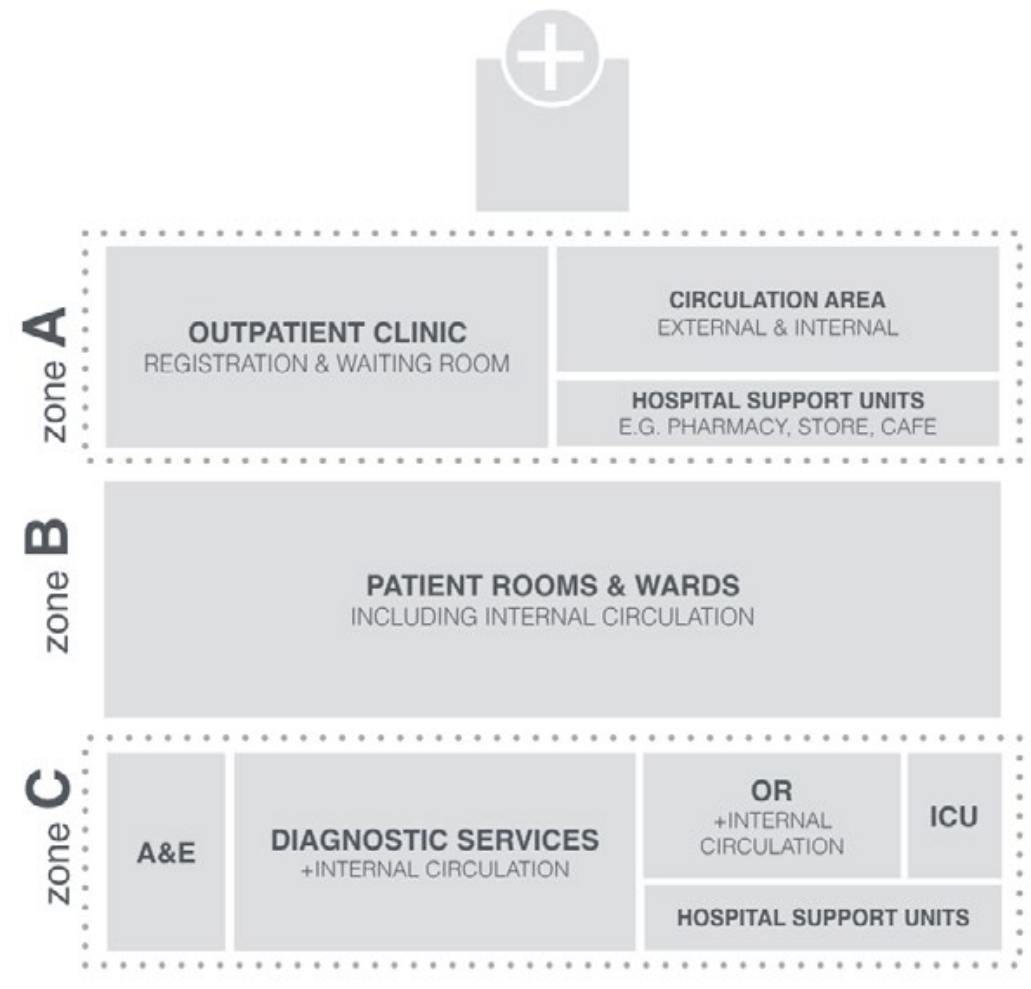

Fig. 2. Schematic hospital layout - division into zones $A, B$, $C$ due to accessibility.

Author: $\mathrm{PhD}$, architect engineer A. Gawlak, MSc architect engineer M. Matuszewska

The first zone A is the so-called external area, which includes the generally accessible halls and corridors, the reception room, the waiting room, the entire entrance area and direct surroundings with the admission room. This zone creates the hospital image. The second zone $B$, is the so-called internal zone, which comprises hospital departments, patients' rooms, circulation in the departments with auxiliary rooms, whereas zone $C$ of diagnostic and treatment rooms is the most specialised and isolated area.

Developing programs of hospital functions, we need to account for the fact that some of the hospitals might be engaged in scientific research or medical instruction activities, i.e. the research and development centres and university clinic hospitals (these types of hospitals conduct medical research and offer instruction to students of medicine). If this is the case, the design shall account for an additional zone i.e. instruction rooms (auditoriums, lecture halls, conference rooms, the library, etc.).

It has become a standard practice to obligatorily subject the role of architects designing such buildings as hospitals to complex medical technologies and strict formal and legal requirements. It, however, leaves no doubt that the architecture of these zones preconditions relevant behaviour of the users. Architectural designs must strictly observe the limitations posed by the functions and technologies indispensable for the diagnostic and treatment zone; yet more freedom can be enjoyed at the designs of common, publicly accessible hospital areas such as the admission rooms, waiting rooms, information points, relaxation areas - here the architects may take a more creative and open approach to designing. These areas offer high creative potential as space dedicated to other purposes than strictly the medical treatment procedures [Fig. 3]. 


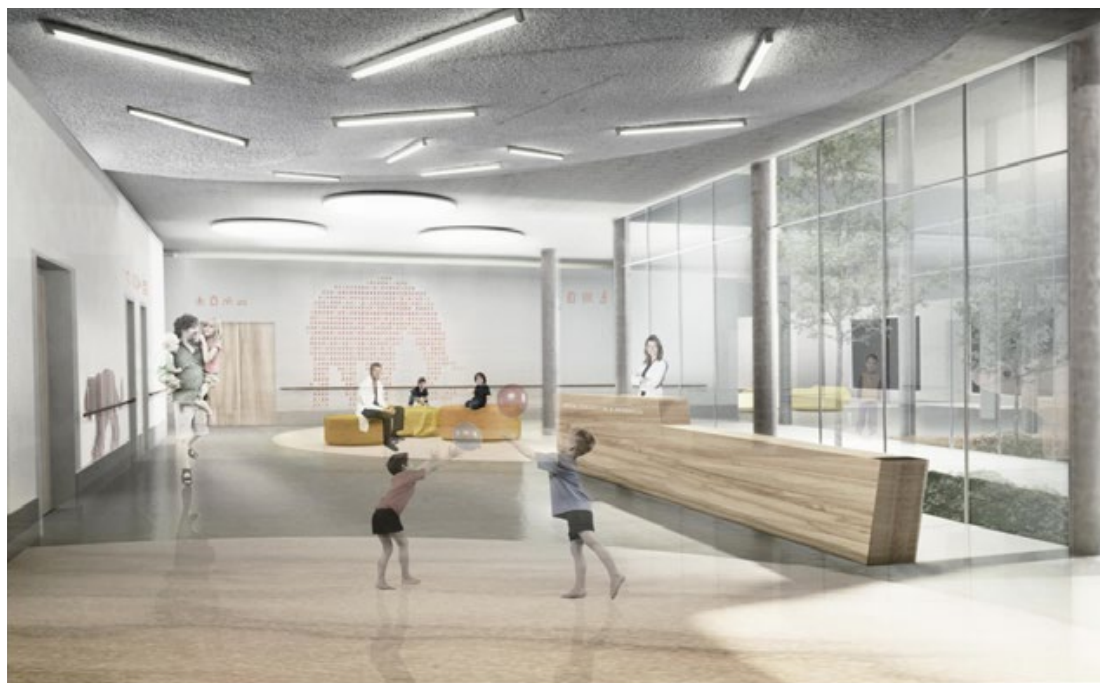

Fig. 3. Interior design of the admission room in a paediatric hospital.

Author: MSc, architect engineer Jan Kądziela; Thesis supervisor: $\mathrm{PhD}$, architect engineer A. Gawlak

Proper diagnosis largely depends on the psychophysical condition of the patient at his/her admission to hospital. It has been confirmed that the symptoms in the youngest patients, who have low adaptability skills, can intensify due to sudden stress (Bell, Greene, Fisher, Baum, 2004).

Public space in modern hospitals usually overwhelms with its grand scale, this is where the architects and designers can use the full potential of their artistic creativity. Despite being the junctions of internal traffic in highly specialised hospitals, these areas make the impression of lightness, uniqueness and uniform compliance with the overall conception. Without doubt, they introduce new quality to the hospital space (Gawlak i Pruszewicz-Sipińska, 2012).

\section{Physical properties of designed hospital space affecting the well-being of its users}

Functions of the hospital buildings can be realised provided that the users of relevant premises/rooms can enjoy overall comfort therein. The comfort criteria to be met differ depending on the areas: some rooms just need ventilation, others require air-conditioning, whereas some premises, which have to be maintained in sterility (operating theatres), must be ensured with air of certain level of microbiological purity.

Design decisions concerning the colour scheme, lighting, equipment are subordinated to the sanitary and hygienic requirements and medical technologies.

Nevertheless, apart from ensuring access to the technically and technologically most advanced design solutions, the patients' well-being must be in the core interest of the architect's activities.

Modern designing consists in the creative work of the entire team of experts, it is, in other words, a search for an optimum solution out of possible options; this often means a reasonable compromise between the postulates of the doctors and the technical and financial possibilities. An architect must always duly care for the efficient use of technological means to achieve possibly the highest aesthetics of the designed spatial layout.

The architect's (author's) task is to properly shape the material environment into attractively looking spatial units to positively affect the patient's mental condition and to facilitate his/her adaptation to unfamiliar surroundings, thus, reducing the patient's stress.

\section{Building block and form}

The hospital location itself is of crucial importance. Apart from the obvious factors such as locating hospitals near agglomerations they are designed to provide services for and in proximity to major road junctions, paediatric, geriatric or other hospitals intended for long-term hospitalisation shall not be located in continuous 
development, they need to be provided with green areas. In case of such hospitals, it is a good practice to so design the departments that the hospitalised patients could face the green areas. Furthermore, hospitals need to be provided with large windows as natural views have therapeutic effects on the patients both as regards their mental condition and physical recovery. The research has shown that the patients who watched the trees through the windows recovered faster than patients with views to the city centre or traffic (Bell., Greene, Fisher, Baum, 2004). [Fig.4]
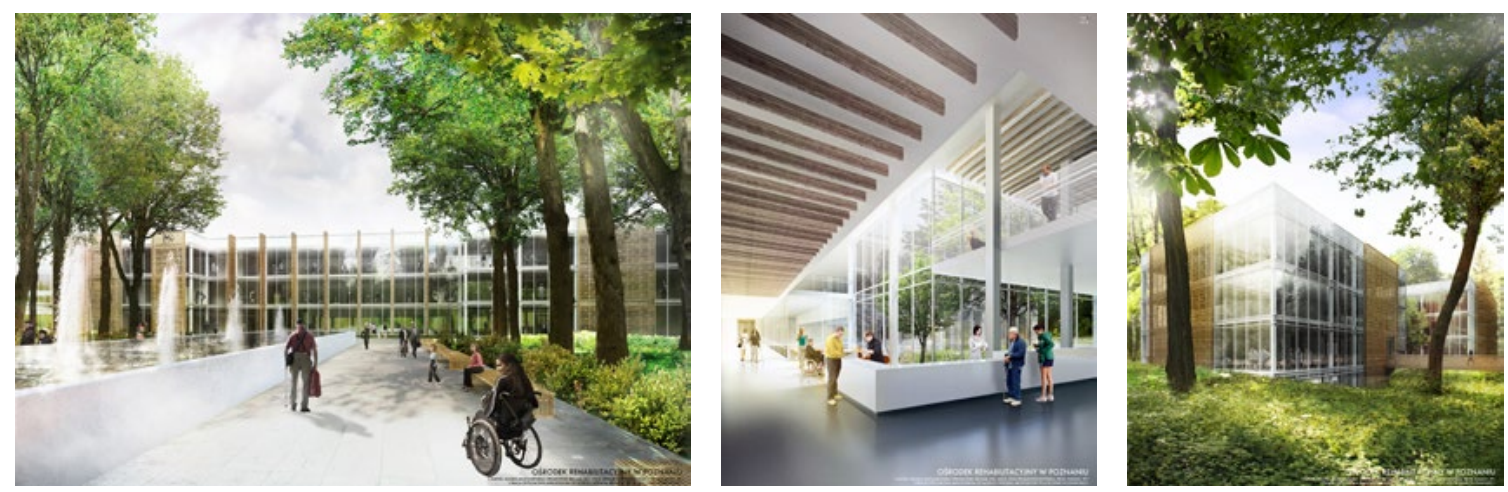

Fig. 4. A design concept of the Rehabilitation Centre in Poznan being part of the rehabilitation and orthopaedic centre within W. Dega hospital (28 Czerwca 1956 Street)

Author: MSc, architect engineer Magda Matuszewska; Thesis supervisor: Prof. architect engineer Ewa Pruszewicz-Sipińska, associate professor at Poznan University of Technology
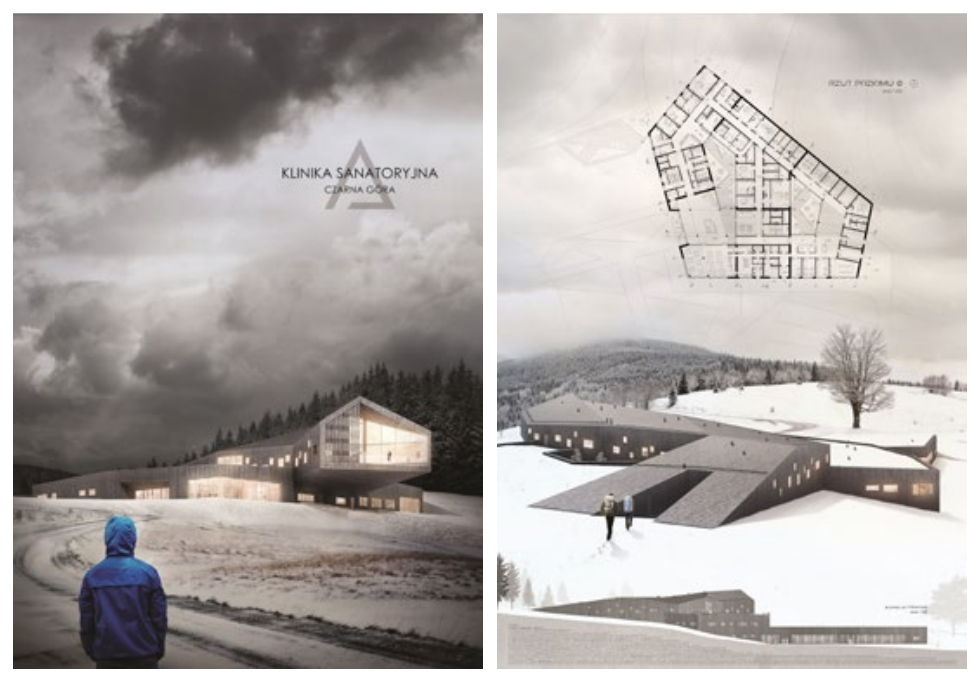

Fig. 5. Diploma design of a sanatorium clinic facility in Czarna Góra in Kotlina Kłodzka (The Kłodzko Valley),

Author: MSc, architect engineer Aleksandra Pocion; Thesis supervisor: PhD, architect engineer A. Gawlak

Negative perception of hospital buildings and stereotypes coined in the last several dozens of years among others result from (according to M. Czyński):

a secluded locations of hospitals, outside the municipal borderlines, with difficult access for the patients and the visitors,

- huge scale of hospital buildings designed for several hundred of beds that makes the impression of an automated treatment process of anonymous patients,

- standardisation of an architectural form - buildings deprived of details, with flat façades with symmetrical rows of windows,

- misleading directional signs to entrances and drives to the hospital buildings that increase stress, alienation and the feeling of loss; no cohesive, visual identification

- lack of aesthetically designed areas around the hospital (gardens or parks). 
Crowded patients' rooms, unfriendly hospital space, complicated circulation, unclear directions, smells of antiseptics and specific sounds make the patients and the visitors feel confused.

Modern approach to designing health care facilities stresses the priority of the quality of architecture [Fig. 5]

With the development of architectural psychology, the context of the patients' treatment process has changed the perception of hospital buildings. A carefully designed hospital building and its form has become a stimulating and facilitating element of the hospitalisation process, resulting in a positive perception of the surroundings by the patient.

Elimination of a gap in the aesthetics of hospital architecture and the architecture of residential development or recreational facilities has changed the sociological and psychological perception of hospitals (they are now less secluded from the urban structure and contradict the stereotypical images of hospitals, old people's homes, etc.) More and more often hospital architecture diverges from the previous practise of hardly accessible, anonymous, huge size buildings, where a user feels alienated. [Fig.6]

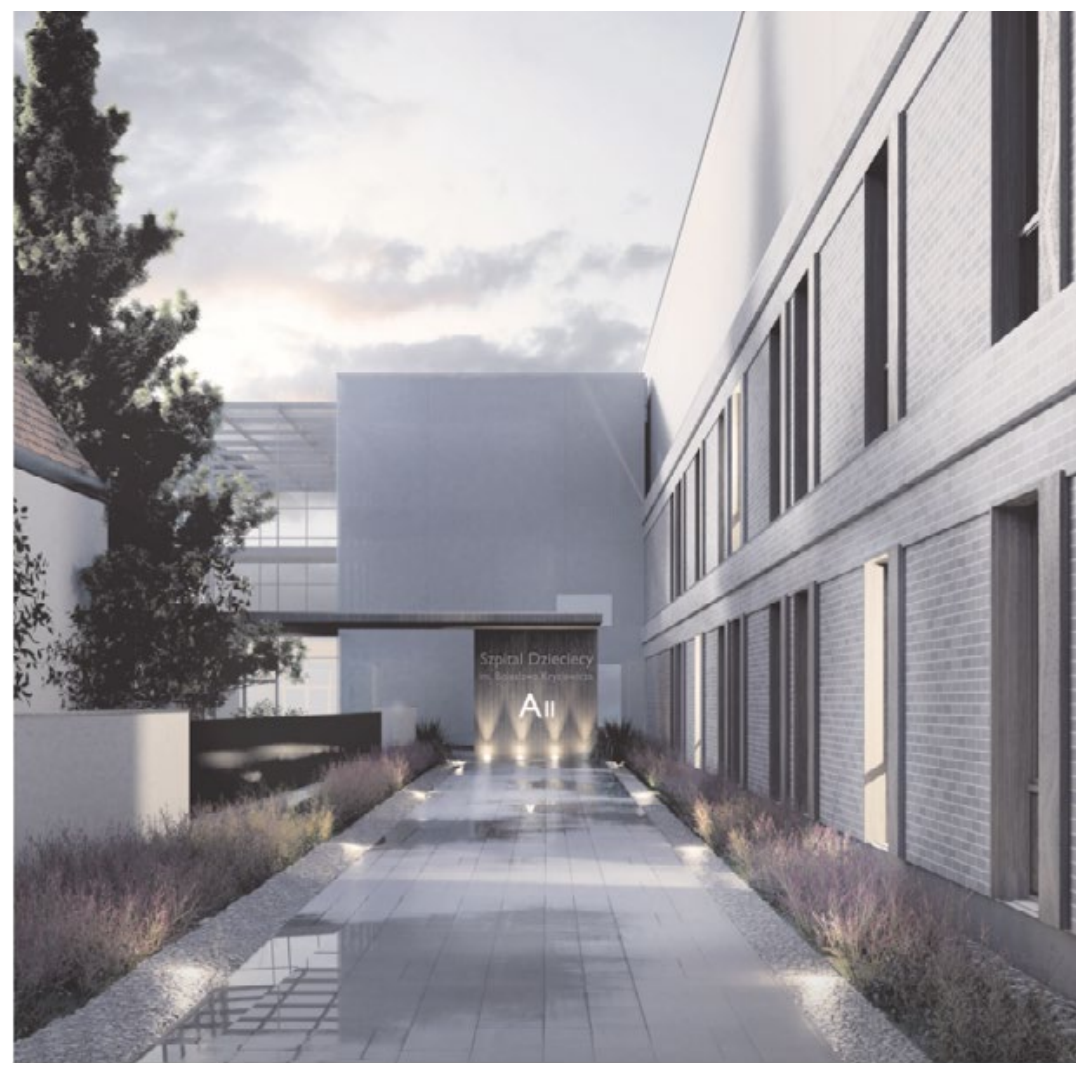

Fig. 6. Design concept of the extension of the hospital at ul. Szpitalna in Poznan.

Author: MSc, architect engineer Marta Sowińska; Thesis supervisor: $\mathrm{PhD}$, architect engineer A. Gawlak

Medical staff appreciates the visitors as their presence positively affects the patient's well-being. They can, furthermore, assist the staff in simple tasks such as the washing or feeding the patient. In hospitals where the patients are in single rooms, the comfort of the visitors is definitely higher that in case of patients in shared rooms. A number of research works (Urlich, 2008) have assessed single rooms as facilitating the recovery process among others due to better sleep and reduction of pain-killers.

It has been also confirmed that patients prefer those functional layouts in hospitals that allow them to watch the medical staff and other patients(Niezabitowska, 2004).

The hospital building block (its form) results from the functional and spatial layout of the building interior but not exclusively. It predetermines the organisation of space around it, affecting the passers-by and random appeasers. [Fig.7] 


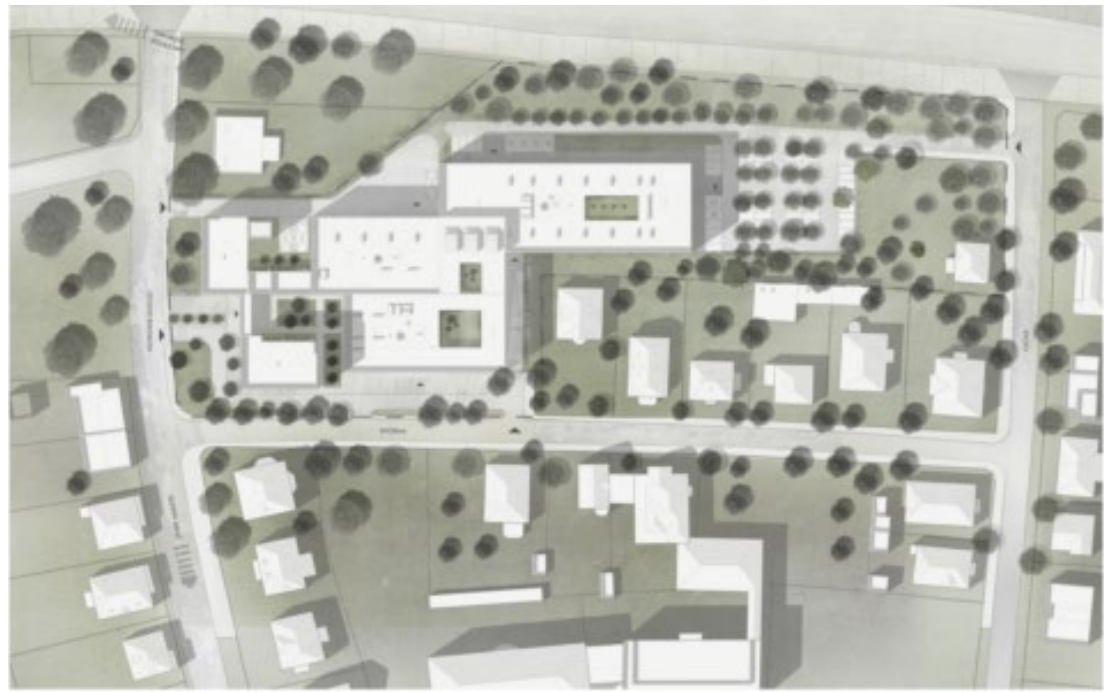

Fig. 7. Design of area development around the hospital at ul. Szpitalna in Poznan.

Author: MSc, architect engineer Jan Kądziela; Thesis supervisor: PhD, architect engineer A. Gawlak

\section{Colour scheme}

As regards hospital space where the majority of the supplies/equipment continuously need to be replaced or modernised, colour is very important. Colour constitutes an inherent feature of any applied material or of each designed space and corresponds to the aesthetics and functionality of the objects. Above all, conscious selection of colours basically is not a medical treatment method. Nevertheless, it has been found that colour pure or monotonous interiors negatively affect the patients' recovery and well-being of personnel. It has been proven that improvement of the visual quality of the interior via appropriate colour scheme and light selection may shorten the recovery rate of the patients by up to $10 \%$. (Dalke and others, 2006).

Sommers succeeded in proving in his research that the reduction of external stimuli, including reduction of colour stimulation in hospital interiors, where patients with limited mobility are hospitalised, may result in dangerous behaviour, in hallucinations in extreme cases.

Furthermore, Alexander Schauss, who in the 1960s and 1970s tested the influence of colours on emotional condition of man and the level of hormones, carried out an experiment, which proved that certain colours can excite or calm down and affect our cardiovascular system. Experimenting first on himself and next on prisoners, he confirmed that "Baker-Miller Pink" significantly reduced stress and calmed one down. His tests are currently being continued by prof. Adam Alter.

Colour scheme selected for the interiors plays a double role: it affects the comfort of users and their feeling of safety and also introduces cohesive visual identification of the hospital space. A uniform visual system improves the hospital organisation, facilitates the staff work and makes it easy for the visitors and the patients to move about the hospital.

Earlier research on the issue, among others by Hilary Dalke, shows that consistent and conscious colour scheme solutions are very important for the elderly patients as they need clear and unambiguous colourful graphic designations. Moreover, certain groups of patients need more time to understand visual information or visual codes (Dalke and others, 2006). Careful introduction of colours translates into more intuitive orientation in a hospital building, which is vital in a situation of a threat or stress. Hospitals are typically extensive, several floor facilities, where one can easily feel lost. This additionally increases the patient's stress and a result impedes the medical interview, examination or a diagnosis. Colour or texture additionally identifies particular functional areas by defining their position in hierarchy, which facilitates spatial orientation in the hospital. This concerns not only the wall colours but also the colours of doors, railings or floor markings that guide the patients e.g. from the main entrance to the patients registration (admission) or further to relevant consultation rooms.

It has been observed that patients better identify colour codes than understand the written instructions about locations of particular hospital areas. (Dalke and others, 2006). At the same time, application of unambiguous 
colours in directional signs (e.g. yellow, red or blue) has turned out to be very effective. On the other hand, application of e.g. cyan could turn out to be confusing as cyan can be identified as green as well as blue. Application of grey is also risky - shades of many colours e.g. purple in particular lighting conditions may look grey, the same is with pink if the elderly persons wear yellow lenses (Dalke and others, 2006).

Senile patients often suffer from disorders in the perception of colours, contrasts, visual signals and perspective. Basically, yellow is the most important for the elderly - it is the last visible and recognisable colour for the persons with declining colour perception.

For the reason of technological processes and medical procedures, selection of the colour scheme in treatment rooms and laboratory rooms is much stricter. In the generally accessible areas, refreshment rooms, circulation paths, etc. colours are subjected to the prevailing goal to evoke certain emotions such as the feeling of relaxation, unwinding, balance and harmony. An individual character of respective rooms derives from colour. This, on the one hand, fosters a positive attitude of the patients to hospitalisation and, on the other hand, stimulates the staff integration and identification with the workplace.

\section{Texture and fit-out}

Selection of surface textures and additional fit-out in hospitals is above all subordinated to sanitary and hygienic aspects. We, however, need to remember that the textures of walls, floors or furniture predetermine the users' perception of the surrounding space. Nice environment is among others used to divert the patients focus from their health problems or the treatment procedure they are awaiting. Appropriate selection of fit-out and textures similarly fosters the well-being of medical staff.

To meet the goal, hospital interiors are also furnished with pieces of art: paintings, bas-reliefs, sculptures, sometimes created by the local artists. In paediatric hospitals, the young patients are often the artists whose drawings decorate the interiors.

The research (Sommer and Ross, 1958) has confirmed a simple inter-dependence between the manner of furnishing the rest and refreshment space in geriatric hospitals and the patients' behaviour. It has been proven that if the interior design of these rooms envisaged the use of round tables, social interactions increased in comparison to dayrooms arranged with rows of chairs. (Cherulnik, 1193; Spasiewicz, 2011).

Just the shape and colour of the furniture affect the psychological condition of the hospital users. The patients respond to the atmosphere created by the interior design and room fit-out. Patients' perception of the rooms as "nice" or "ugly" directly translates into their comfort and indirectly - into efficiency of the treatment. Furthermore, patients allowed to customise their hospital space, respond more positively to hospitalisation, feeling more independent.

It has been proven that suggestive perception of the interior quality contributes to increased social interactions at the hospital department, which improves mental condition of the patients (Bell., Greene, Fisher, Baum, 2004). In this respect we may also refer to the theory of Jan Gehl, which maintains that the increased quality of space translates into higher activity of the users and better prosocial behaviour.

\section{Lighting}

The Polish Standard PN-EN-12464-1 on Lighting of Indoor Work Places contains the general information pertaining to the lighting requirements in health care facilities. There are several fundamental criteria, which underlie the concept of good lighting - safety, good visibility, visual comfort and aesthetics.(Gawlak and Pruszewicz-Sipińska, 2012). The elderly persons, due to weak eyesight and reduced perception and cognitive abilities, require twice as much light as prescribed in the standards. Appropriate lighting helps them to understand the spatial orientation and to read the identification system. Proper light intensity is particularly important for dementia patients because they suffer from disturbed ability of processing visual signals.

In the first, external zone of the hospital (A), the lighting can intentionally make a good first impression and the exposure of the entrance zone, well-communicated with the main reception and the waiting room makes it easier for the patients to find the right way. This is especially important if the patient is stressed. The lighting 
usually corresponds to the overall concept of the visual information and spatial identification in a building (Gawlak and Pruszewicz-Sipińska, 2012).

\section{Observance of privacy and the right to privacy}

According to a declaration of the Patient Rights' Ombudsman, Krystyna Barbara Kozłowska, 9 thousand complaints were filed in 2009 concerning the breach of patients' rights, in 2010 this number went up to 28 thousand and in 2012 - to 48 thousand. The majority of the complaints filed with the Medical Chamber concerned the disrespect of the patient's right to privacy in hospital - during examination, convalescence, etc. The patients mainly complained about unwanted exposure to visual inspection by other patients or visitors.

Obviously, the conditions of hospitalisation in certain hospitals and limited space at the departments do not allow for the accommodation of single patients' rooms, still movable screens, dividers and additional lobbies can improve the patients' comfort during their hospitalisation.

Ergonomic and proxemic method of identification of stresogenic factors allows for the analysis of interdependencies between the structure of space and the behavioural and social context of architecture (Czyński, 2006). The method takes into account the overall range of biological and psychosomatic needs of man as well as the cultural specifics, including the proxemics (comfortable distance to another person) as these aspects affect the relations between the users and the man-made environment and fundamentally underlie the feeling of safety inside a building.

It must be pointed out that the users with limited motor abilities, health disorders or a variety of malaises appreciate the individual right of free choice in man-made environment where full freedom must be subjected to medical or diagnostic restrictions. Certain stresogenic factors deriving from the spatial layouts can be consciously reduced by the designer via elimination of unwanted interference. In terms of space, these may be: the reduction of a number of patients in one room, isolated entrances to the surgery rooms, no direct insight into the patients' rooms, provision of mobile screens in the patients' rooms, allocation of visitors' space outside the patients' rooms. The attractively designed and fitted-out dayrooms with several round tables or circularly arranged armchairs and sofas that can diverge the patients' attention from the hospital boredom (e.g. artistic classes, workshops, presentations etc.) can be used as the said visitors' space. The aforementioned solutions, furthermore, foster prosocial reactions, facilitate new relationships, positively affect the mental condition of the patients and their internal motivation to fully recover.

It often happens that the patients crowd in a relatively small area in front of the admission room. High congestion, lack of privacy, peculiar 'hospital sounds' generate stress and cause excessive excitation.

Whereas the entire hospital admission procedure require detailed medical information from the patient or their guardians. It should be carried out in peaceful atmosphere, where the interviewee can concentrate on the answers. If the reception area has no separate room dedicated to medical interviews, no privacy is observed and this is another stresogenic factor that may affect the reliability of the answers provided by the patient.

Adaptation of reception desks to mobile abilities of the patients (including those on wheelchairs) and designing reception areas with patients' privacy in mind were viewed as priority requirements for the admission zone by the respondents (patients) (Dalke and others, 2006).

\section{Conclusions}

Designing health care facilities is a task that requires interdisciplinary knowledge on medical technologies, psychology, physiology, sociology and anthropology of man.

This article has presented the impact of functional and spatial solutions upon the behaviour of the building users, among others via appropriate building form or its fit-out.

We have, furthermore, referred to the new research on the influence of the colour scheme and lighting on human behaviour and to quality assessment methods in order to evaluate the architecture of hospitals.

Furthermore, a building user is viewed as an important participant in the process of working out the building functions and in architectural designing. In case of hospital buildings, these users are: the patients, the medical 
personnel and the visitors. It has been confirmed that colour and lighting facilitates the patients' adaptation to hospital conditions. Additionally, colour plays an important role in directional signs and visual identification of hospital areas, which reduces stress and improves the perception of safety and the overall positive experience of the patients. All the factors that are directly related to the technological, functional and spatial solutions applied in hospitals underlie the patients' comfort and the quality of his/her hospitalisation.

\section{References}

[1] Abrams Ch. (1971). The Language of Cities: A Glossary of Terms, 1, wg Marty Spasiewicz.

[2] Adams A., Theodore D., Goldenberg E., McLaren C., McKeever P. (2010). Kids in the atrium: Comparing architectural intentions and child's experiences in a pediatric hospital lobby, Social Science \& Medicine 70, str. 658-667.

[3] Bańka A. (1985). Psychologiczna struktura projektowa środowiska. Studium przestrzeni architektonicznej". Poznań: Wydawnictwo Politechniki Poznańskiej.

[4] Bell P.A., Greene Th.C., Fisher J.D., Baum A. (2004). Psychologia środowiskowa. Gdańsk: Gdańskie Wydawnictwo Psychologiczne.

[5] Cherulnik P.D. (1193). Applications of Environment-Behavior Research: Case Studies and Analysis. Cambridge: Cambridge University Press.

[6] Czyński M. (2006). Architektura w przestrzeni ludzkich zachowań. Wybrane zagadnienia bezpieczeństwa w środowisku zbudowanym. Szczecin: Wydawnictwo Uczelniane Politechniki Szczecińskiej.

[7] Dalke H., Little J., Niemann E., Camgoz N., Setadman G., Hill S., Stott L. (2006). Colour and lighting in hospital design. Optics and Laser Technology 38, str. 243-365.

[8] Gawlak A., Matuszewska M., Szuba P., Jakość przestrzeni architektonicznej dedykowanej ochronie zdrowia a potrzeby mieszkańców w kontekście założeń idei healthy cities na przykładzie Poznania, PUA Przestrzeń Urbanistyka Architektura, 1/2018, DOI: 10.4467/00000000PUA.18.002.8610

[9] Gawlak A., Matuszewska M., Szuba P, Personnel-centred study for advancing the quality of hospital care, European Healthcare Design 2018, Sallus, Londyn 2018, http://www.salus.global/article-show/ehd2018-p08, dostęp:07.07.2018

[10] Gawlak A., Pruszewicz-Sipińska E. (2013). Architektura przestrzeni ogólnodostępnej w szpitalu. Pacjent i personel, Pielęgniarstwo Polskie 4/2013. Poznań: Wydawnictwo Naukowe Uniwersytetu Medycznego.

[11] Gehl J. (2009). Życie między budynkami. Użytkowanie przestrzeni publicznych. Cracow: Wydawnictwo RAM.

[12] Juraszyński J., Nitsch A., Porębowicz S., Radwański R. (1973). Projektowanie obiektów służby zdrowia. Warszawa: Wydawnictwo Arkady.

[13] Lenartowicz J.K. (2007). Słownik psychologii architektury. Cracow: Wydawnictwo Politechniki Krakowskiej.

[14] Meuser P. (2010). Construction and Design Manual. Medical Practices. Building Typologies Public Health. Berlin: Wydawnictwo DOM publishers.

[15] Nickl H., Nickl-Weller Ch. Hospital Architecture (2007). Wirginia: Wydawnictwo Verlagshaus Braun.

[16] Niezabitowska E. (red). (2004). Wybrane elementy facility management w architekturze. Gliwice: Wydawnictwo Politechnik Śląskiej.

[17] Pawłowska K. (red). (2010). Zanim wybuchnie konflikt. Idea i metody partycypacji społecznej w ochronie krajobrazu i kształtowaniu przestrzeni. Cracow: Foundation - Fundacja Partnerstwo dla Środowiska.

[18] Pruszewicz-Sipińska E. (red). (2015). Architecture \& Health. Poznań.

[19] Spasiewicz M. (2011). Architektura i partycypacja. Czasopismo Miasto i obywatel 36.

[20] Ulrich R. S. (2008). A Review of the Research Literature on Evidence-Based. Healthcare Design, Health Environments Research \& Design, 1(3).

[21] Zumthor P. (2010). Myślenie architekturą, Karakter, Kraków 